\title{
PENGARUH KUOTA EKSPOR TERHADAP HARGA KARET DOMESTIK INDONESIA
}

\section{The Effect of Export Quotas on Indonesia's Domestic Natural Rubber Prices}

\author{
Alfi Nurdina ${ }^{1^{*}}$, Harmini ${ }^{2}$, Amzul Rifin $^{2}$ \\ 1Program Studi Agribisnis IPB University, Kampus IPB Dramaga, Bogor, \\ Jawa Barat, 16680 Indonesia \\ 2Departemen Agribisnis IPB University, Kampus IPB Dramaga, Bogor, \\ Jawa Barat, 16680 Indonesia \\ Email: alfinurdina03@gmail.com
}

Naskah diterima: 21/07/2021; Naskah direvisi: 20/09/2021; Disetujui diterbitkan: 19/11/2021; Dipublikasikan online: 24/12/2021

\begin{abstract}
Abstrak
Agreed Export Tonnage Scheme merupakan kebijakan pembatasan kuota ekspor karet alam oleh Indonesia, Malaysia dan Thailand. Kebijakan ini diduga memengaruhi harga karet alam di tingkat petani. Penelitian ini bertujuan untuk menganalisis pengaruh kebijakan kuota ekspor terhadap harga karet alam domestik Indonesia di tingkat petani. Penelitian menggunakan data time series bulanan dari Januari 2013 sampai Desember 2019 menggunakan Error Correction Model. Dalam jangka panjang, harga karet alam pada periode sebelumnya, nilai tukar, konsumsi, produksi dan harga karet alam dunia signifikan. Sementara itu, dalam jangka pendek, harga karet alam pada periode sebelumnya, nilai tukar, dan harga karet alam dunia juga signifikan. Variabel total ekspor dan dummy kebijakan tidak signifikan baik dalam jangka panjang maupun jangka pendek. Hal ini diduga karena harga karet alam tidak lagi bergantung pada faktor fundamental tetapi disebabkan oleh faktor eksternal lainnya. Perbaikan diperlukan, termasuk desain kebijakan yang komprehensif, implementasi dan evaluasi teknis yang jelas, serta kolaborasi tambahan dengan produsen karet alam lainnya. Selain itu, sejalan dengan kebijakan pembatasan ekspor, Indonesia perlu mendorong pertumbuhan industri pengolahan karet alam menjadi produk hilir.
\end{abstract}

Kata Kunci: ECM, Karet Alam, Harga Domestik, AETS

\begin{abstract}
Agreed Export Tonnage Scheme is a policy of limiting natural rubber export quotas by Indonesia, Malaysia, and Thailand. This policy is suspected to affect the price of natural rubber at the farm level. This study aims to analyze the effect of the export quota policy on Indonesia's domestic natural rubber prices at the farm level. The study uses monthly time series data from January 2013 to December 2019 used Error Correction Model. In the long term, natural rubber prices in the previous period, exchange rate, consumption, production, and world natural rubber prices are significant. Meanwhile, in the short term, natural rubber prices in the previous period, exchange rates, and world price natural rubber were significant. The variable total exports and the policy dummy are not significant both in the long and short term. This is presumably because natural rubber prices no longer depend on fundamental factors but are caused by other external factors. Improvements are needed, including comprehensive policy design, clear technical implementation, and evaluation, as well as additional collaboration with other natural rubber producers. In addition, in line with
\end{abstract}

https://doi.org/10.30908/bilp.v15i2.609

Published by Trade Analysis and Development Agencies, Ministry of Trade. This is an open access article under the CC BY-NC-SA 4.0 license (http://creativecommons.org/licenses/by-nc-sa/4.0/) 
the export restriction policy, Indonesia needs to encourage the growth of the natural rubber processing industry into downstream products

Keywords: ECM, Natural Rubber, Domestic Price, AETS

JEL Classification: Q17, Q18, Q21

\section{PENDAHULUAN}

Ada lima belas komoditas unggulan perkebunan yang dianggap memiliki nilai ekonomis tinggi serta berperan penting dalam meningkatkan kesejahteraan masyarakat. Kelima belas komoditas tersebut antara lain cokelat/kakao, karet, kelapa sawit, kopi, dan tembakau (Suwarto et al., 2014).

Sebagai komoditas unggulan pertanian, karet tidak lepas dari berbagai permasalahan, satu diantaranya adalah penurunan harga. Oleh karena itu, Indonesia masuk menjadi anggota International Tripartiate Rubber Council (ITRC) bersama dua negara lainnya yakni Thailand dan Malaysia. Kerja sama internasional ini bertujuan untuk menjaga produksi karet alam berkelanjutan dan menerapkan strategi kebijakan bersama yang relevan untuk mencapai stabilitas harga karet alam yang remuneratif bagi petani karet alam sehingga dapat meningkatkan kesejahteraannya. Berkaitan dengan tujuan tersebut, negara-negara anggota ITRC bersepakat untuk mengatur kebijakan-kebijakan yang wajib dilaksanakan oleh negara-negara anggota dan juga sebagai badan yang akan bertanggung jawab untuk mengkoordinasikan dan mengawasi implementasi dari aturan-aturan yang ditetapkan.

Direktorat Jenderal Perundingan Perdagangan Internasional (2018), ada tiga kebijakan yang diambil ITRC yaitu: (1) Supply Management Scheme (SMS) atau skema pengendalian produksi, (2) Agreed Export Tonnage Scheme (AETS) atau skema pengendalian penawaran ekspor, dan (3) Demand Promotion Scheme (DPS) atau skema peningkatan permintaan karet alam domestik. Salah satu kebijakan yang dilakukan ITRC adalah Agreed Export Tonnage Scheme (AETS), yaitu pengendalian/ pengurangan pasokan karet alam di pasar dunia pada saat terjadi kelebihan pasokan, sementara permintaan sedikit. Skema pengurangan ekspor ini bertujuan untuk meningkatkan harga karet alam dunia.

Kebijakan Agreed Export Tonnage Scheme diatur dalam Keputusan Menteri Perdagangan (Kepmendag) Nomor 779 Tahun 2019 tentang 
Pelaksanaan Agreed Export Tonnage Scheme (AETS) ke-6 untuk Komoditas Karet Alam. Dalam kebijakan tersebut, jumlah ekspor karet alam yang dikurangi yaitu sebesar 240.000 ton selama empat bulan (April-Juli 2019). Jumlah tersebut dibagi secara proporsional sesuai dengan jumlah produksi masing-masing negara, Thailand tertinggi disusul Indonesia dan Malaysia paling sedikit. Dengan demikian, ekspor karet Indonesia dikurangi sebesar 98.160 ton. Komoditi karet alam yang dikurangi sesuai dengan kesepakatan ITRC ini meliputi karet alam jenis Concentrated Latex/Centrifuged Latex yang termasuk dalam kode HS 400110; karet alam berjenis Ribbed Smoked Sheet Rubber (RSS) yang termasuk dalam kode HS 400121; produk karet alam jenis Technically Specified Rubber (TSR) yang termasuk dalam kode HS 400122; karet alam jenis Mixture Rubber yang termasuk dalam kode HS 400280; serta karet alam dengan jenis Compounded Rubber yang termasuk dalam kode HS 400510, 400520, 400591, dan 400599.

Adapun alokasi jumlah komoditi karet alam yang dapat diekspor untuk periode 1 April sampai dengan 31 Juli 2019 sebesar 941 ribu ton, dengan rincian bulan April sebesar 256,8 ribu ton; bulan Mei sebesar 245 ribu ton; bulan Juni sebesar 173,8 ribu ton; dan bulan Juli 2019 sebesar 266 ribu ton.

Untuk Indonesia, tanggung jawab pelaksanaan pembatasan ekspor diberikan kepada Gapkindo. Hal ini dikemukakan dalam Purwaningrat (2019) dimana Gapkindo bertugas untuk mengawasi serta menyerap karet alam petani saat adanya kebijakan. Penyerapan karet alam petani ini ditujukan agar petani tidak kehilangan pasarnya saat ekspor dibatasi.

Produksi karet alam Indonesia berasal dari perkebunan rakyat $(\mathrm{PR})$, perkebunan swasta (PBS) dan perkebunan milik negara (PBN) dengan jumlah penguasaan tertinggi berada pada perkebunan rakyat.

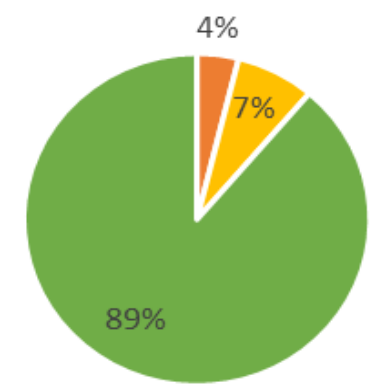

$$
\begin{aligned}
& \text { Perkebunan } \\
& \text { Besar Negara } \\
& \text { (Ton) } \\
& \text { - Perkebunan } \\
& \text { Besar Swasta } \\
& \text { (Ton) } \\
& \text { - Perkebunan } \\
& \text { Rakyat (Ton) }
\end{aligned}
$$

\section{Gambar 1. Produksi Karet Alam Berdasar Status Penguasaan Lahan, 2019}

Sumber: Pusdatin, Kementan (2021)

Dari Gambar 1 tampak bahwa perkebunan rakyat memproduksi $89 \%$ dari total produksi karet alam ada tahun 2019. 
Petani karet tidak memiliki kekuatan dalam memengaruhi harga. Harga karet alam terbentuk oleh pasar, sedangkan petani ataupun produsen karet merupakan price taker. Hal tersebut dibuktikan oleh analisis dari Amalia, Nurmalina, \& Rifin (2013) analisis integrasi pasar vertikal baik jangka pendek maupun jangka panjang menyimpulkan bahwa petani cenderung sebagai penerima harga (price taker).

Harga karet yang rendah akan berdampak pada turunnya pendapatan dan rendahnya kesejahteraan. Sampai dengan Maret 2020 harga komoditas karet tumbuh negatif 5,3\% (BI, 2020). Saat ini dengan situasi banyak rumah tangga yang bergantung pada karet justru harga karet semakin fluktuatif. Petani yang sudah terlanjur menanam karet sulit untuk bertahan. Pilihan untuk mengalih fungsi lahan tidak serta merta dapat dilakukan. Hal tersebut dikarenakan keuntungan yang didapat masih belum menutupi modal investasi penanaman di awal pembudidayaan. Selain itu diperlukan biaya pembersihan lahan jika memang akan dialih fungsi. Menurut Elvawati et al. (2019) petani yang memiliki penguasaan lahan lebih besar memiliki akses terhadap modal yang lebih baik sehingga lebih mudah untuk alih fungsi. Sedangkan, untuk petani lahan sempit seperti halnya petani transmigran tidak melakukan alih fungsi.

Kebijakan AETS yang dilakukan oleh tiga negara memang bertujuan untuk meningkatkan harga karet dunia. Meski demikian, Kementerian Perdagangan (2019) menjelaskan bahwa diharapkan dengan kenaikan harga karet dunia, harga karet di tingkat petani juga mengalami peningkatan. Beberapa penelitian mengungkapkan pengaruh harga karet alam dunia terhadap harga karet alam di tingkat petani. Purwaningrat, Novianti, \& Dermorejo (2019) menemukan bahwa dengan adanya penurunan penawaran ekspor tahunan oleh Indonesia, Malaysia dan Thailand mengakibatkan ketidakseimbangan pasar. Sebagai akibatnya harga karet alam dunia meningkat sebesar 4,32\%. Lebih lanjut, Pramananda (2019) menemukan bahwa kenaikan harga karet dunia akan berpengaruh pada kenaikan harga karet alam petani.

Uraian di atas menunjukkan bahwa dampak kebijakan AETS perlu dikaji lebih lanjut secara empiris, baik dari segi implementasi dan dampaknya terhadap petani karet. Penelitian sebelumnya, yakni Purwaningrat, Novianti, \& Dermorejo (2019) 
menggunakan data tahunan, menunjukkan bahwa kebijakan AETS mampu mendorong harga karet alam dunia. Harga karet alam dunia ini kemudian ditransmisikan pada harga karet alam petani. Lebih lanjut Pramananda (2019) tidak menemukan pengaruh ekspor Indonesia terhadap harga karet alam bulanan petani. Namun penelitian Pramananda (2019) hanya mengkaji pengaruh ekspor Indonesia terhadap harga karet alam di tingkat petani, dan tidak memasukkan pengurangan ekspor dari dua negara lainnya yakni Malaysia dan Thailand. Selanjutnya implementasi kebijakan AETS juga penting diketahui untuk melihat kepatuhan tiap negara melaksanakan kebijakan bersama pembatasan ekspor karet alam. Berdasarkan berbagai uraian sebelumnya, penelitian ini bertujuan untuk mengkaji dua hal: menganalisis implementasi kebijakan pembatasan ekspor (AETS) oleh tiga negara; dan menganalisis Pengaruh kebijakan pembatasan ekspor (AETS) terhadap harga karet alam domestik Indonesia.

\section{METODE}

Penelitian ini menggunakan data sekunder time series bulanan dari Januari 2013 sampai Desember 2019 berjumlah 84 observasi. Data yang dikumpulkan berupa data harga karet alam domestik yang merupakan harga rata-rata produsen pedesaan 10 provinsi produsen karet terbesar di Indonesia; produksi total karet alam Indonesia; konsumsi total karet alam Indonesia; jumlah ekspor karet alam Indonesia, Thailand, dan Malaysia dengan HS 400110, 400121, 400122, 400280, 400510, 400520, 400591, dan 400599; dummy kebijakan AETS; nilai tukar; harga karet alam dunia dan harga minyak bumi dunia. Data tersebut diperoleh dari Kementerian Pertanian (2020), World Bank (2021), Bank Indonesia (2021), Trademap (2020), Gapkindo (2020). Referensi studi kepustakaan melalui jurnal, artikel, perpustakaan LSI Institut Pertanian Bogor dan internet yang relevan dengan penelitian ini.

Metode analisis yang digunakan dalam penelitian ini yaitu analisis kuantitatif. Analisis kuantitatif digunakan untuk mengetahui pengaruh kebijakan pembatasan kuota ekspor terhadap harga karet alam domestik Indonesia. Pengolahan data menggunakan pendekatan Error Correction Model (ECM), sedangkan estimasi model menggunakan software Eviews 7.0.

Melalui metode ECM ini dapat diperoleh hubungan jangka panjang 
dan jangka pendek dari variabelvariabel yang akan dianalisis. Dalam bukunya, Banarjee et al. (1993) menjelaskan bahwa jangka panjang adalah suatu periode waktu saat semua variabel telah mencapai keseimbangan, biasanya didefinisikan dalam periode di atas satu tahun. Sedangkan untuk jangka pendek adalah suatu periode waktu untuk mencapai keseimbangan pada jangka panjang, biasanya didefinisikan dalam periode waktu enam sampai dua belas bulan.

Variabel-variabel yang diteliti dalam penelitian ini merupakan hasil dari referensi teori dan penelitianpenelitian terdahulu. Adapun variabel ekspor karet alam tiga negara dan dummy pembatasan ekspor merupakan variabel utama yang dianalisis pengaruhnya terhadap peningkatan harga karet alam domestik di tingkat petani.

Selain itu juga digunakan variabel lainnya seperti harga pada periode sebelumnya, harga karet dunia, kurs, harga minyak bumi, produksi dan konsumsi untuk melihat keragaman faktor pembentuk harga karet alam domestik. Harga karet periode sebelumnya dimasukkan untuk mengatasi masalah autokorelasi pada model ECM. $\begin{array}{ccc}\text { Model } & \text { persamaan } & \text { untuk } \\ \text { menganalisis } & \text { faktor-faktor } & \text { yang } \\ \text { memengaruhi } & \text { harga karet } & \text { alam }\end{array}$ Indonesia dalam jangka panjang dirumuskan sebagai berikut dengan $\mathrm{t}$ merupakan periode bulanan:

$$
\begin{aligned}
& \text { Pdom }=a_{0}+a_{1} \text { LPdom }_{t-1}+a_{2} \text { LProd }_{t}+ \\
& a_{3} \text { LEksTot } t_{t} a_{4} \mathrm{LPoil}_{t}+a_{5} \mathrm{LKon}_{t} \\
& +a_{6} \text { LKurs }_{t}+a_{7} \text { Dumeks } t+a_{8} \\
& \text { Pdunia } t+e t
\end{aligned}
$$

Proses transformasi persamaan ke dalam bentuk logaritma natural agar estimasi dapat dinyatakan dalam bentuk elastisitas. $\mathrm{Hal}$ tersebut dikarenakan dalam bentuk biasa, satuan atau skala antar variabel masih berbeda. Sehingga diperlukan transformasi untuk menyatukan satuan variabel-variabel tersebut. Kemudian, model persamaan jangka pendek dirumuskan sebagai berikut: $\Delta \mathrm{Pdom}=b_{0}+b_{1} \Delta \mathrm{LPdom}_{t-1}+b_{2} \Delta \mathrm{LProd}_{t}$ $+b_{3} \Delta$ LEksTot $t-3+b_{4} \Delta$ LPoil $_{t}+$ $b_{5} \Delta$ LKon $t+b_{6} \Delta$ LKurs $t+b_{7}$ Dumeks $t+b_{8} \Delta$ Pdunia $_{t}+\gamma u$ $t-1+$
et

Di mana Pdom: harga rata-rata karet alam lump tingkat petani pada periode ke t $(\mathrm{Rp} / \mathrm{kg})$; Pdom $t-1$ : harga rata-rata karet alam lump tingkat petani pada periode sebelumnya $(\mathrm{Rp} / \mathrm{kg})$; Prodt: produksi total karet alam Indonesia 
periode ke $\mathrm{t}$ (ribu Ton); Kon $t$ : konsumsi total karet alam Indonesia periode ke $\mathrm{t}$ (ribu Ton); Poil $t$ : harga minyak bumi dunia pada periode sebelumnya $(\$ / \mathrm{kg})$; EksTott: ekspor karet alam total tiga negara (Indonesia, Thailand, Malaysia) pada periode ke t meliputi HS 400110, 400121, 400122, 400280, 400510, 400520, 400591, dan 400599 (ribu ton); Kurs $t$ : nilai tukar dollar terhadap rupiah pada periode ke $\mathrm{t}(\mathrm{Rp} / \mathrm{kg})$; Pduniat: harga karet alam dunia pada periode ke t (Rp/kg); Dumeks: dummy kebijakan pembatasan ekspor (1: ada kebijakan pembatasan ekspor; 0: tidak ada kebijakan pembatasan ekspor); $\mathrm{t}$ : periode bulanan; $a_{0}$ : konstanta persamaan jangka Panjang; $a_{i}$ : koefisien regresi variabel bebas ke i $(\mathrm{i}=$ $1,2, \ldots, 7)$ persamaan jangka panjang; $b_{0}$ : konstanta persamaan jangka pendek; $b_{i}$ : koefisien regresi variabel bebas ke i ( $\mathrm{i}=1,2, \ldots, 7)$ persamaan jangka pendek; $\gamma$ : koefisien error term; $u_{t-1}$ : error correction term; et: error persamaan jangka pendek.

\section{Uji Model}

Pada penelitian ini uji yang digunakan meliputi uji stioneritas, uji kointegrasi, uji asumsi klasik, uji T dan uji F. Data time series diharuskan data yang diolah stasioner, menurut Gujarati (2012) jika deret waktu nonstasioner, kita hanya dapat mempelajari perilakunya untuk periode yang dipertimbangkan, tidak mungkin untuk menggeneralisasikannya ke periode waktu lain dan analisis regresi yang melibatkan deret waktu tersebut dapat mengarah pada fenomena regresi lancung. Uji kointegrasi dipopulerkan oleh Engle dan Granger (Gujarati, 2012), untuk mendeteksi adanya kointegrasi maka dilakukan uji augmented dickey fuller pada error.

Uji $F$ ditujukan untuk mengukur tingkat hubungan secara keseluruhan koefisien regresi dari variabel independen tehadap variabel dependen. Untuk memperkuat hasil uji, koefisien determinasi $\left(R^{2}\right)$ juga perlu dihitung. Semakin tinggi nilai $\mathrm{R}^{2}$, maka semakin besar keragaman variabel dependen yang bisa dijelaskan variabel independen. Nilai $\mathrm{R}^{2}$ di antara 0 sampai 1 atau jika dituliskan dalam persen antara 1-100 \%. Nilai $R^{2}$ dapat menjelaskan keragaman model, sedangkan sisanya $\left(1-R^{2}\right)$ dijelaskan oleh komponen error atau variabel diluar model.

Uji $\mathrm{T}$ digunakan untuk melihat pengaruh masing-masing variabel independen terhadap variabel dependen. Nilai probabilitas yang umum dipilih adalah $10 \%, 5 \%$, dan $1 \%$. 
Nilai-nilai ini dikenal sebagai tingkat signifikansi oleh karena itu disebut uji signifikansi t (Gujarati, 2012).

Dalam melakukan pemodelan data time series dengan menggunakan OLS, harus dilakukan uji asumsi klasik. Uji asumsi klasik merupakan uji prasyarat statistik yang mengunakan analisis regresi, hal ini dilakukan agar model yang didapatkan sesuai dengan kriteria-kriteria statistik yang ada seperti uji autokorelasi, multikolinearitas, heterokedastis, dan normalitas

\section{HASIL DAN PEMBAHASAN}

Berdasarkan hasil uji, semua persyaratan untuk penggunaan model
ECM sudah terpenuhi. Uji stasioneritas yang dilakukan pada semua variabel semuanya stasioner pada differencing pertama. Begitupun pada uji kointegrasi, stasioner pada data level.

Uji asumsi klasik yang meliputi uji normalitas, uji multikolinearitas, uji autokorelasi dan uji heterokedastitas juga telah memenuhi syarat. $\mathrm{Uji}$ normalitas, uji autokorelasi, uji heterokedastisitas masing-masing sebesar 0,258; 0,78; dan 0,22. Nilai VIF pada uji multikolinearitas juga menunjukkan angka dibawah 10 sehingga dapat disimpulkan tidak ada masalah multikolinearitas.

Tabel 1. Estimasi Jangka Panjang

\begin{tabular}{lll}
\hline \multicolumn{1}{c}{ Variable } & Coefficient & \multicolumn{1}{c}{$P$-Values } \\
\hline harga karet periode sebelumnya & 0,711086 & $0,0000^{* * *}$ \\
Kurs & 0,345774 & $0,0000^{* * *}$ \\
konsumsi & 0,150740 & $0,0031^{* * *}$ \\
ekspor total tiga negara & $-0,00156$ & 0,9659 \\
dummy kebijakan ekspor & $-0,00959$ & 0,1632 \\
harga minyak bumi & 0,016803 & 0,1898 \\
Produksi & $-0,07344$ & $0,0752^{*}$ \\
harga karet dunia & 0,240627 & $0,0000^{\star * *}$ \\
Konstanta & $-1,07656$ & $0,0180^{* * *}$ \\
& & \\
R-Square & 0.955594 & \\
F-Prob & $0,0000^{* * *}$ & \\
\hline
\end{tabular}

Uji $\mathrm{F}$ pada jangka panjang $\mathrm{R}$ square adjusted dari persamaan maupun jangka pendek memberi nilai jangka panjang sebesar 0,95 artinya probabilititas yang lebih kecil daripada taraf nyata $1 \%$ hingga dapat dikatakan bahwa model tersebut sudah baik. Nilai keragaman harga karet domestik yang dapat dijelaskan oleh variabel-variabel independen sebesar 95\% dan sisanya 
adalah error. Sedangkan untuk dapat dijelaskan model sedangkan persamaan jangka pendeknya sebesar 0,56 yang artinya $56 \%$ keragaman sisanya dijelaskan oleh variabel lain diluar model atau error.

Tabel 2. Estimasi Jangka Pendek

\begin{tabular}{|c|c|c|}
\hline Variable & Coefficient & $P$-Values \\
\hline harga karet periode sebelumnya & 0,725318 & $0,0000^{\star \star \star}$ \\
\hline Kurs & 0,248414 & $0,0848^{*}$ \\
\hline Konsumsi & 0,060424 & 0,2746 \\
\hline ekspor total tiga negara & $-0,00563$ & 0,8623 \\
\hline dummy kebijakan ekspor & $-0,00342$ & 0,6205 \\
\hline harga minyak bumi & 0,014336 & 0,6817 \\
\hline Produksi & $-0,02613$ & 0,5833 \\
\hline harga karet dunia & 0,248214 & $0,0000^{* * *}$ \\
\hline ECT & $-0,93294$ & $0,0000^{* \star *}$ \\
\hline Konstanta & 0,001378 & 0.6504 \\
\hline R-Square & 0.564566 & \\
\hline F-Prob & $0,0000^{\star * *}$ & \\
\hline
\end{tabular}

Dalam model jangka pendek dihasilkan koefisien Error Correction Term. ECT memiliki koefisien sebesar 0,759661, nilai negatif dan signifikan menandakan model ECM valid dan dapat digunakan untuk persamaan jangka panjang dan juga jangka pendek. Nilai ECT tersebut secara absolut kurang dari 1. Nilai ECT dalam model menurut Gujarati (2012) merupakan speed of adjustment, yakni koefisien yang menentukan seberapa cepat model dapat mengoreksi kesalahan yang terjadi pada jangka pendek untuk mencapai keseimbangan pada jangka panjangnya. Nilai 0,93 ini menunjukkan bahwa 93\% kesalahan dalam jangka pendek akan terkoreksi dalam jangka panjang dan merupakan tingkat penyesuaian yang cepat.

Harga karet pada periode sebelumnya signifikan pada jangka pendek maupun jangka panjang pada taraf nyata $1 \%$. Data yang digunakan dalam persamaan ini sudah ditranformasi kedalam bentuk logaritma natural. Oleh karena itu, untuk tiap kenaikan harga karet periode sebelumnya sebesar $1 \%$, maka harga karet alam domestik saat ini akan naik 
sebesar $0.71 \%$ pada jangka panjang. Sedangkan pada jangka pendek akan meningkat $0,72 \%$. Harga karet pada periode sebelumnya tergolong inelastis. Hasil yang sama pernah ditemukan dalam Pramananda (2019), Aji (2010) dan Anggita (2016) yang menyatakan bahwa harga komoditas dipengaruhi oleh harga komoditas itu sendiri pada periode sebelumnya. Aji (2010) menambahkan bahwa nilai yang signifikan pada estimasi mengisyaratkan bahwa pelaku pasar tidak hanya mempertimbangkan permintaan dan penawaran namun juga mempertimbangkan harga pada periode sebelumnya.

Ekspor total tiga negara tidak berpengaruh pada jangka panjang maupun jangka pendek terhadap harga karet alam di tingkat petani. Begitupun dengan dummy kebijakan ekspor. Artinya di bulan-bulan adanya kebijakan tidak ditemukan adanya perubahan yang signifikan. Padahal ketiga negara adalah produsen karet dunia, terutama Thailand dan Indonesia. Temuan yang sama juga ada pada penelitian lain oleh Haryanto, Sunariyo, \& Mukti (2019) yang membuktikan ekspor karet Indonesia tidak signifikan memengaruhi harga karet alam domestik. Hal tersebut diduga dikarenakan AETS bukan lagi faktor fundamental yang memengaruhi harga karet di Indonesia.

Konsumsi berpengaruh pada jangka panjang namun tidak berpengaruh pada jangka pendek. Temuan hubungan signifikan antara konsumsi dan harga karet alam didukung oleh temuan Fong, Khin, \& Lim (2020). Baik jangka panjang maupun jangka pendek memiliki tanda koefisien yang positif artinya pergerakan konsumsi dan harga karet alam domestik searah. Kenaikan konsumsi domestik terhadap produk karet alam akan membuat permintaan terhadap karet di petani menjadi naik juga. Kenaikan permintaan inilah yang akan direspon dengan kenaikan harga di tingkat petani. Meskipun begitu dalam jangka pendek variabel konsumsi tidak signifikan pengaruhnya. Hal ini bisa disebabkan karena biasanya pabrik memiliki stok atau persediaan karet. Sehingga kenaikan permintaan bisa diatasi dengan adanya stok tersebut. Pada penelitian Pramananda (2019) konsumsi juga ditemukan tidak memengaruhi harga karet domestik pada jangka pendek, namun penelitian lain oleh Haryanto, Sunariyo, \& Mukti (2019) dan Khin \& Thambiah (2015) justru menemukan hal yang sebaliknya. 
Produksi berpengaruh pada jangka panjang namun tidak berpengaruh pada jangka pendek. Temuan ini didukung oleh penelitian Khin dan Tambiah (2015) dan Fong, Khin, \& Lim (2020). Kenaikan produksi akan menyebabkan kelebihan supply dan mendorong penurunan harga. Namun sebagai produk ekspor seringkali harga karet mengikuti harga Internasionalnya, karena itu produksi domestik tidak terlalu signifikan memengaruhi harga karet. Namun pada jangka panjang produksi ini akan mampu memengaruhi harga karet dikarenakan Indonesia merupakan produsen besar karet alam, artinya Indonesia memiliki kekuatan untuk memengaruhi pasar karet alam dunia.

Harga karet alam dunia memiliki nilai probabilitas dibawah $1 \%$ dan koefisien sebesar 0,24. Nilai 0,24 mengindikasikan tingkat kepekaannya inelastis. Meskipun begitu nilai koefisien yang dihasilkan memiliki nilai yang signifikan, artinya harga dunia berpengaruh terhadap pembentukan harga karet alam domestik. Hal ini merupakan konsekuensi dari perekonomian terbuka, selain itu karet merupakan komoditi ekspor unggulan Indonesia. Lebih dari $70 \%$ produksi karet ditujukan untuk kepentingan ekspor. Sehingga harga dari pasar dunia dan pasar domestik saling berintegrasi. Integrasi antara pasar karet ini pernah ditemukan dalam penelitian Daulika, Peng, \& Hanani, (2020) yang menemukan korelasi antara harga dunia dengan harga ekspor dan Raju (2016) yang menemukan integrasi tinggi antara harga dunia dan harga domestik. Harga ekspor karet Indonesia inilah yang ditransmisikan kepada harga karet di petani. Sehingga kenaikan atau penurunan harga pada pasar dunia akan turut memengaruhi harga karet di petani.

Kurs merupakan variabel selanjutnya yang memiliki nilai $p$-values yang signifikan pada taraf nyata $1 \%$ untuk jangka panjang dan signifikan pada taraf nyata $10 \%$ pada jangka pendek. Hasil tersebut sama dengan penelitian Daulika, Peng, \& Hanani, (2020) yang juga menemukan hubungan signifikan antara nilai tukar dan harga karet alam ekspor. Pada jangka panjang Nilai koefisien kurs sebesar 0.34 artinya jika kurs naik $1 \%$ maka harga karet alam domestik akan naik $0,34 \%$. Sedangkan koefisien pada jangka pendek lebih kecil. Hal ini sejalan dengan (Haryanto, Sunariyo, \& Mukti (2019) dan (Fong, Khin, \& Lim, 
2018) yang menemukan bahwa nilai tukar rupiah terhadap dollar memengaruhi pembentukan harga karet dalam jangka panjang. Kurs yang dimaksud dalam penelitian ini adalah jumlah rupiah yang didapatkan untuk tiap dollar yang ditukarkan. Sehingga kenaikan kurs yang dimaksud dalam penelitian ini adalah pelemahan nilai rupiah atau penguatan nilai dollar. Perdagangan karet dilakukan dengan US dollar, maka nilai tukar rupiah yang melemah membuat para eksportir mendapatkan harga yang lebih tinggi. Harga ini yang selanjutnya ditransmisikan ke harga karet di petani.

Selain itu ada variabel yang tidak signifikan baik jangka panjang maupun jangka pendek yakni harga minyak bumi. Harga minyak bumi tidak ada hubungan jangka panjang dan jangka pendek yang ditemukan antara harga minyak mentah dan harga karet alam, Mereka berhubungan positif tetapi tidak signifikan secara statistik (Fong, Khin, \& Lim, 2018)

\section{Pengaruh Kebijakan AETS Terhadap Harga Karet Alam Domestik}

Dalam kurun waktu tahun 20122019 setidaknya sudah empat kali kebijakan ini diterapkan.

1. Kebijakan AETS pada tahun 20122013. Menurut Direktorat Jenderal
Perkebunan (2012), volume pengurangan ekspor karet sebesar 300 ribu ton, yang diberlakukan sejak Oktober 2012 sampai Maret 2013.

2. Kebijakan AETS pada tahun 2016 menurut Kementrian Perindustrian (2016) dilakukan selama enam bulan, mulai 1 Maret-31 Agustus 2016. Alokasi pengurangan ekspor bagi tiap negara yaitu Thailand sebanyak 324 ribu ton, Indonesia 238 ribu ton, dan Malaysia 52 ribu ton.

3. Kebijakan AETS pada tahun 2018 menurut Liputan 6 (2018) dilakukan pada bulan Januari-Maret. Pada kebijakan tersebut ketiga negara mengurangi 350 ribu ton ekspor karet alam.

4. Kebijakan AETS pada tahun 2019. Menurut Kepmendag No. 779 Tahun 2019 pengurangan ekspor dilakukan terhadap karet alam jenis 400110, 400121, 400122, 400280, 400510, 400520, 400591, 400599 Kebijakan tersebut mengurangi ekspor karet alam sebanyak 240 ribu ton untuk ketiga negara tersebut, Indonesia mengurangi ekspor karetnya sebanyak 98 ribu ton, Malaysia membatasi ekspor karetnya sebesar 15,6 ribu ton, dan Thailand sebagai 
produsen karet alam nomor satu di dunia mengurangi volume ekspornya sebanyak 126,2 ribu ton. Penerapan kebijakan AETS tahun 2019 menurut Liputan 6 (2019) dilaksanakan selama 4 bulan terhitung dari bulan April-Juli untuk Indonesia dan Malaysia. Sedangkan Thailand melaksanakanya pada bulan Mei-September.

Pada penelitian ini pengaruh AETS terhadap harga karet alam domestik dilihat dari dua variabel yakni ekspor total tiga negara dan dummy pembatasan eskpor. Kedua variabel tersebut baik jangka panjang maupun jangka pendek tidak signifikan memengaruhi harga karet domestik di tingkat petani. Kebijakan ini pada dasarnya memang bertujuan menaikkan harga karet dunia, namun diharapkan dengan kenaikan harga karet dunia harga karet di petani juga ikut naik. Korelasi antara harga dunia dan harga domestik terbukti dalam penelitian ini dan didukung penelitian lain seperti halnya (MdLudin, Applanaidu, \& Hussin, 2016).

Sayangnya di bulan-bulan adanya AETS harga karet di petani justru turun. Contohnya saja pada AETS tahun 2018, menurut data harga rata-rata produsen yang dipublikasi oleh
Kementan bulan desember 2017, harga karet di tingkat petani sekitar Rp 7100/kg, namun akhir bulan Maret 2018 harganya justru turun menjadi Rp $6749,5 / \mathrm{kg}$.

Ada beberapa alasan yang mungkin menjadi penyebab AETS tidak signifikan memengaruhi harga karet di tingkat petani. Pertama karena efek ekspor bukan lagi menjadi faktor fundamental dalam penentuan harga karet alam melainkan faktor eksternal lain. Kedua karena rancangan kebijakan yang kurang efektif.

Pembatasan ekspor tidak memengaruhi harga karet petani diduga karena pengurangan ekspor tidak berpengaruh pada kenaikan harga karet dunia. Fong, Khin, \& Lim (2020) menyatakan hal ini dikarenakan bahwa faktor di balik harga karet alam dunia tidak bisa lagi dijelaskan semata-mata oleh faktor fundamentalnya (kekuatan penawaran-permintaan pasar normal). Menurut sumber dari Katadata (2018) Ketua Umum Gabungan Pengusaha Karet Indonesia (Gapkindo) Moenardji Soedarjo membenarkan AETS belum signifikan dalam meningkatkan harga jual karet dunia.

Harga karet sebagian besar dipengaruhi oleh banyak faktor nonfundamental atau faktor luar seperti 
nilai tukar riil dan aliran dana spekulatif di pasar bursa berjangka (Fong, Khin, \& Lim, 2020). ARBC (2019) juga melaporkan bahwa pada tahun 2018 juga terjadi perang dagang antara China dan AS yang menimbulkan ketidakpastian. Orang akan takut berproduksi sehingga mereka tidak menggunakan bahan baku karet. China adalah salah satu importir terbesar karet dari Asia tenggara. Menurut penelitian Oktora \& Firdani (2019), Arus perdagangan tidak hanya ditentukan produksi negara eksportir tapi juga permintaan negara importir seperti China. Penumpukan persediaan di negara tujuan ekspor akan mengurangi permintaan karet dari negara produsen dan turunnya harga karet alam.

Kebijakan AETS ini bukanya tanpa kelemahan. Permasalahan yang muncul dalam kebijakan ini salah satunya adalah kepatuhan tiap negara yang sulit untuk dinilai. Kebijakan ini hanya mencantumkan jumlah ekspor yang harus dikurangi. Namun, tidak ada keterangan mengenai periode yang menjadi pembanding. Misalnya saja periode pada tahun sebelumnya atau bulan sebelumnya. Pada kenyataanya pada tahun-tahun diterapkanya kebijakan justru ada indikasi kenaikan jumlah ekspor.
Tabel 3. Perkembangan Ekspor Total Tiga Negara Tahun 2013-2019

\begin{tabular}{ccc}
\hline & $\begin{array}{c}\text { Ekspor Karet } \\
\text { Total (ribu ton) }\end{array}$ & $\begin{array}{c}\text { Pertumbuhan } \\
(\%)\end{array}$ \\
\hline 2013 & 8320 & - \\
2014 & 8020 & $-4 \%$ \\
2015 & 8010 & $0 \%$ \\
2016 & 8160 & $2 \%$ \\
2017 & 9310 & $14 \%$ \\
2018 & 9060 & $-3 \%$ \\
2019 & 8100 & $-11 \%$ \\
\hline
\end{tabular}

Pada tabel 3 terlihat bahwa kebijakan AETS tahun 2016 mengindikasikan pertumbuhan ekspor positif $2 \%$.

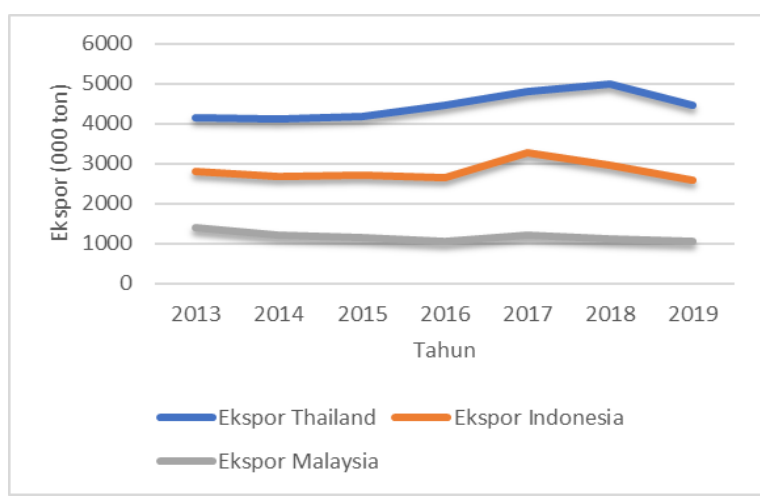

Sumber: Trademap (2021), diolah

Gambar 2. Perkembangan Ekspor Tahunan Karet Alam Tiga Negara, 2013-2019

Gambar 2 juga menunjukkan bahwa Kebijakan tahun 2018 membuat ekspor tahunan karet alam Malaysia dan Indonesia turun, akan tetapi Thailand justru ekspornya naik. 
Begitupun pada penerapan AETS keempat tahun 2016, Ekspor karet Thailand menunjukkan peningkatan sedangkan Malaysia dan Indonesia turun. Melihat hal tersebut ada indikasi ketidakpatuhan Thailand yang merupakan produsen ekspor terbesar. Menurut laporan ARBC (2019) dan ARBC (2018) pada tahun 2018 Thailand juga mengalami peningkatan ekspor pada triwulan pertama 2018. Ekspor karet Thailand yang awalnya sebesar 950.993 ton pada JanuariMaret 2017 menjadi 1.004.200 ton pada Januari-Maret 2018. Padahal dua negara lainya Indonesia dan Malaysia mencatatkan penurunan karena sedang menerapkan AETS.

Sayangnya hingga saat ini tindakan evaluasi yang menjadi tolok ukur keberhasilan tidak pernah diumumkan hasilnya dan tidak dijelaskan detail teknisnya. Tindakan pelanggaran dapat merugikan kepada pihak yang patuh. Negara yang tidak patuh dapat mengekspor dalam jumlah yang lebih tinggi. Sehingga efek pembatasan ekspor karet dunia yang sudah ditetapkan menjadi kurang efektif. Terutama jika hal tersebut dilakukan pemegang share tertinggi ekspor karet alam, yang pada dasarnya diharapkan menghasilkan efek lebih besar pada kenaikan harga karet alam.

Kebijakan pembatasan ekspor yang dilakukan ternyata tidak ada jaminan dilaksanakan sesuai dengan kesepakatan, begitupun ternyata dampak yang ditimbulkan oleh kebijakan tersebut ternyata tidak memperbaiki harga karet alam petani. Padahal pihak yang paling bermasalah dengan harga rendah adalah petani.

Untuk menyiasati ini tentunya perlu ada perbaikan dalam perancangan dan pelaksanaan kebijakan. Perancangan kebijakan yang dilakukan secara bulanan tampaknya tidak terlalu efektif. Negara pengimpor bisa meningkatkan stoknya sebelum kebijakan dimulai. Di sisi lain, tiga negara ITRC bisa melakukan antisipasi dengan pengalihan ekspor sebelum kebijakan atau sesudah kebijakan. Sehingga ketika kebijakan berlangsung, kekurangan pasokan pasar tidak terlalu dirasakan dan menjadi tidak efektif. Oleh karena itu perlu rancangan jangka panjang untuk tiga negara tersebut mengurangi ekspor. Kebijakan yang bisa lebih panjang periodenya bukan hanya 3-6 bulan. Perlu juga klausul tambahan untuk tidak mengalihkan ekspor ke periode lainnya dalam kurun 
waktu tertentu. Dengan kebijakan yang kontinu dapat mengatasi efek lag. Selain itu, tindakan evaluasi terhadap implementasi juga harus dibuat sedetail mungkin. Harus ada poin yang menerangkan periode apakah yang digunakan sebagai dasar pembanding pada implementasi turunnya ekspor. Serta sanksi apabila kuota tidak terpenuhi sesuai kesepakatan.

Selain itu, seiring dengan kebijakan pembatasan ekspor, Indonesia perlu untuk terus mendorong tumbuhnya usaha pengolahan karet alam menjadi produk hilir. Tumbuhnya usaha pengolahan karet alam akan mendorong peningkatan permintaan karet alam domestik dan penciptaan nilai tambah karet alam di dalam negeri. Indonesia harus meniru Malaysia dalam pembangunan Industri karet alam. Menurut Fong, Khin, \& Lim (2020) Malaysia sedang mengalami transisi dari pengekspor menjadi pengimpor karet alam. Selain itu menurut Ardanari dan Mukiwihando (2020) impor karet alam juga dilakukan untuk pengolahan lebih lanjut melalui pencampuran karet alam yang diproduksi Malaysia sendiri untuk kemudian diekspor kembali.

\section{KESIMPULAN DAN REKOMENDASI KEBIJAKAN}

Pada jangka panjang variabel yang signifikan adalah harga karet periode sebelumnya, kurs, konsumsi, produksi dan harga karet dunia. Sedangkan pada jangka pendek yang signifikan adalah harga karet periode sebelumnya, kurs, dan harga karet dunia.

Pembatasan ekspor karet alam oleh tiga negara Indonesia, Thailand, dan Malaysia tidak efektif menaikkan harga karet di petani berdasarkan hasil uji terhadap variabel ekspor tiga negara dan dummy kebijakan ekspor. Hal tersebut diduga karena AETS sudah bukan lagi menjadi faktor fundamental yang memengaruhi pembentukan harga dunia maupun harga domestik di tingkat petani. Selain itu rancangan aturan pembatasan ekspor dan implementasinya kurang efektif. Perlu perbaikan meliputi perancangan kebijakan yang kontinu, teknis implementasi dan evaluasi yang jelas, serta penambahan kerjasama dengan produsen karet alam lain. Selain itu seiring dengan kebijakan pembatasan ekspor, Indonesia perlu untuk terus mendorong tumbuhnya industri pengolahan karet alam menjadi produk hilir. 


\section{UCAPAN TERIMAKASIH}

Penulis mengucapkan terima kasih kepada Gapkindo yang telah bersedia memberikan data untuk keberlangsungan penelitian.

\section{DAFTAR PUSTAKA}

Aji, B. W. (2010). Analisis Integrasi Harga Minyak Bumi, Minyak Kedelai, Cpo, Minyak Goreng Domestik Dan Tandan Buah Segar Kelapa Sawit. Thesis. Bogor: Sekolah Pascasarjana IPB.

Amalia, D. N., Nurmalina, R., \& Rifin, A. (2013). Sistem Pemasaran Karet Rakyat Di Provinsi Jambi dengan Pendekatan Struktur, Perilaku, dan Kinerja Pasar. Jurnal Buletin RISTRI, Vol. 4 (3), pp. 237-244. .

Anggita, Dian. (2016). Analisis FaktorFaktor yang Mempengaruhi Harga Kedelai Lokal di Indonesia. Skripsi. Bogor: Program Sarjana IPB.

ARBC. (2018, Oktober 6). Natural Rubber Statistic. Diunduh tanggal 19 September $2021 \quad$ dari http://aseanrubber.net/arbc/nr stats/N o 1 2019.pdf

ARBC. (2019, Agustus 24). Natural Rubber Statistic. Diunduh tanggal 19 September 2021 dari http://aseanrubber.net/arbc/nr stats/N o 1 2019.pdf

ARBC. 2019. Natural Rubber Price Chart. September 2021 dari http://aseanrubber.net/arbc/images/nr pricechart 2019.pdf

Ardanari, Sinta D. dan Mukiwihando, R. (2020). Daya Saing Ekspor Karet Alam Tiga Negara ITRC (Indonesia, Thailand, Malaysia) Di Pasar Internasional Periode 1994-2018. Jurnal Manajemen Keuangan Publik, Vol. 4(1), pp. 81-87.

Banarjee, A., Dolado, JJ., Galbraith, JW. dan Hendry, DF. (1993). Co- integration, Error Correction, and the Econometric Analysis of NonStationary Data (Advanced Texts in Econometrics). Oxford (UK): Oxford University Press.

Bank Indonesia. (2020). Tinjauan Kebijakan Moneter Maret 2020. Diunduh tanggal 19 Oktober 2020 dari:

https://www.bi.go.id/id/publikasi/kebija kanmoneter/tinjauan/Pages/TinjauanKebijakan-Moneter-Maret-2020.aspx

Bank Indonesia. (2021). Kurs Transaksi Bank Indonesia. Diunduh pada tanggal 28 Januari 2021 dari https://www.bi.go.id/.

Daulika, P., Peng, K.-C., dan Hanani, N. (2020). Analysis On Export Competitiveness And Factors Affecting Of Natural Rubber Export Price In Indonesia. Agricultural SocioEconomics Journal, Vol. 20(1), pp. 39-44.

Direktorat Jenderal Perkebunan. (2012, Oktober 14). Peluang Perluasan Karet di Indonesia Masih Terbuka Lebar?. Diunduh tanggal 27 April 2021 dari https://ditjenbun.pertanian.go.id/2012/

Direktorat Jenderal Perundingan Perdagangan Internasional. 2018, April 18. International Tripartite Rubber Council (ITRC). Diunduh tanggal 19 Mei 2020 dari https://ditjenppi.kemendag.go.id/index .php/apec-oi/organisasi-komoditiinternasional/itrc

Elvawati, Dharmawan, Arya H., Damanhuri, Didin S., Sumarti, T. (2019). 'Dari Karet Ke Sawit': Transformasi Struktur Nafkah Rumah Tangga Petani Lokal Dan Petani Transmigran Di Minangkabau. Jurnal sosiologi pedesaan, Vol. 7(2), pp. 86-97.

Fong, Y. C., Khin, A. A., \& Lim, C. S. (2018). Conceptual Review And The Production, Consumption And Price Models Of The Natural Rubber Industry In Selected Asean Countries 
And World Market. Asian Journal of Economic Modelling, Vol. 6(4), pp. 403-418.

Fong, Yi C., Khin, A.A., \& Lim, C.S. (2020). Determinants of Natural Rubber Price Instability for Four Major Producing Countries. Pertanika J. Soc. Sci. \& Hum., Vol. 28(2), pp. 1179 - 1197

Gabungan Perusahaan Karet Indonesia. 2020 (Gapkindo). Data Konsumsi Karet Alam Bulanan Untuk Indonesia Dari Januari 2013-Desember 2019. Indonesia (ID): Gapkindo.

Gabungan Perusahaan Karet Indonesia. 2020 (Gapkindo). Data Produksi Karet Alam Bulanan Untuk Indonesia Dari Januari 2013-Desember 2019. Indonesia (ID): Gapkindo.

Gujarati, Damodar. (2012). Econometric By Example. US: Palgrave Macmillan.

Haryanto, Sunariyo, \& Mukti, A. (2019). Analisis Faktor-Faktor Yang Mempengaruhi Produksi Dan Permintaan Karet Alam. J-SEA (Journal Socio Economics Agricultural), Vol. 14 (1), pp. 11-22.

Katadata. (2018, Mei 7). Pemerintah Evaluasi Efektivitas Pembatasan Ekspor Karet. Diunduh tanggal $10 \mathrm{Mei}$ 2021 dari

https://katadata.co.id/muchamadnafi/b erita/5e9a55f750e9c/pemerintahevaluasi-efektivitas-pembatasanekspor-karet/

Kementrian Perdagangan. (2019, April 1). Upayakan Harga Remuneratif Bagi Petani Karet, Mendag Tetapkan Implementasi AETS ke-6. Diunduh tanggal 21 Maret 2021 dari https://www.kemendag.go.id/storage/f iles/2019/04/01/upayakan-hargaremuneratif-bagi-petani-karetmendag-tetapkan-implementasi-aetske-6-id0-1554091983.pdf

Kementrian Perindustrian. 2016, Maret 10. Gapkindo Dukung Penyerapan Karet Lokal. Diunduh tanggal 9 Mei 2021 dari

https://kemenperin.go.id/artikel/14705
/Gapkindo-Dukung-PenyerapanKaret-Lokal

Kementrian Pertanian. (2021). SIM harga: Laporan Harga Produsen Pedesaan. Diunduh tanggal 28 Januari 2021 dari http://aplikasi2.pertanian.go.id/simhar ga2017/produsen/hpd1/

Keputusan Menteri Perdagangan (Kepmendag) Nomor 779 Tahun 2019 tentang Pelaksanaan Agreed Export Tonnage Scheme (AETS) ke-6. 2019. Jakarta.

Khin, A. A., dan Thambiah, S. (2015). Natural Rubber Prices Forecasting Using Simultaneous Supply-Demand and Price System Equation and VECM Model: Between Theory And Reality. Proceeding of the 2nd International Conference on Agriculture and Forestry, ICOAF-2015 Colombo, Sri Lanka.

Liputan 6. (2018, Februari 10). Pembatasan Ekspor Picu Kenaikan Harga Karet Dunia. Diunduh tanggal 10 Mei 2021 dari https://www.liputan6.com/bisnis/read/ 3274780/pembatasan-ekspor-picukenaikan-harga-karet-dunia

Liputan 6. (2019, April 1). Selain RI, Thailand dan Malaysia Ikut Pangkas Ekspor Karet Alam. Septian Deny. Diunduh tanggal 20 April 2021 dari https://www.liputan6.com/bisnis/read/ 3931411/selain-ri-thailand-danmalaysia-ikut-pangkas-ekspor-karetalam

MdLudin, N., Applanaidu, S., \& Hussin, A. (2016). An Econometric Analysis of Natural Rubber Market In Malaysia. International Journal of Environmental \& Agriculture Research (IJOEAR), Vol. 2(6), pp. 2454-1850.

Oktora, S. I., \& Firdani, A. M. (2019). Natural Rubber Economics between China and Southeast Asia: The Impact of China's Economic Slowdown. Journal of Asian Finance, Economics and Business, Vol. 6(2), pp. 55-62 . 
Pramananda, Penggawa P. (2019). Analisis Pengaruh Tingkat Konsumsi Karet Alam Dalam Negeri Terhadap Harga Karet Alam Indonesia. Skripsi. Bogor: Program Sarjana IPB.

Purwaningrat, L., Novianti, T. dan Dermoredjo, S.K. (2019). Dampak Penerapan Agreed Export Tonnage Scheme (AETS) Terhadap Kesejahteraan Petani Karet Indonesia. Jurnal Penelitian Karet, Vol 37 (2), pp. 127 - 138

Purwaningrat, Linda. (2019). Dampak Kebijakan International Tripartite Rubber Council (ITRC) Terhadap Kesejahteraan Petani Karet Indonesia. Tesis. Bogor: Sekolah Pascasarjana IPB.

Pusat data dan Sistem Informasi Kementrian Pertanian (Pusdatin). (2021). Outlook karet 2020. Jakarta (ID) Kementrian Pertanian
Raju, K. (2016). Instability in Natural Rubber Prices in India: An Empirical. IOSR Journal of Economics and Finance (IOSR-JEF), Vol. 7(3), pp. 24-28.

Suwarto, Octavianty, Y., \& Hermawati, S. (2014). Top 15 Tanaman Perkebunan. Jakarta: Penebar Swadaya.

TradeMap. (2021). Bilateral trade between Indonesia and World Product: 400110, 400121, 400128, 4005. Diunduh pada tanggal 28 Januari 2021 dari https://www.trademap.org/.

World Bank. (2021). Monthly Prices. Diunduh pada tanggal 21 Maret 2021 dari

https://www.worldbank.org/en/researc h/commodity-markets. 
